\title{
Design and Simulations of Solid Oxide Fuel Cell connected to 3-phase electrical power system
}

\author{
Shubham Joshi ${ }^{1 *}$ and D.K. Rai ${ }^{2}$ \\ ${ }^{1 *}$ Dept. of Electrical and Electronics, SVCE, RGPV Indore (M.P.) India \\ ${ }^{2}$ Dept. of Electrical Department, SVCE, RGPV Indore (M.P.) India \\ *Corresponding Author: shubhjoshi.93@gmail.com
}

Available online at: www.isroset.org

Received: 20/Nov/2017, Revised: 30/Nov/2017, Accepted: 08//Dec/2017, Published: 31/Dec/2017

\begin{abstract}
The integration of the fuel cell system is to provide the continuous power supply to the load as per the demand. In this paper, design and modeling of Solid Oxide Fuel cell (SOFC) is discussed for the distributed generation applications. Modeling and simulations are carried out in MATLAB Simulink platform. Solid oxide fuel cells operate at temperatures near $10000 \mathrm{C}$ these are highly efficient combined heat and electric power. Modeling of SOFC is done by using by using Nernst equation. In that the output power of the fuel cell can be controlled by controlling the flow rate of the fuels used in the process.

The power generation from the fuel cell system is an electrochemical reaction between hydrogen and oxygen with the biproduct of water vapour molecule. But the output power from the solar system is very low for this numbers of cell are connected in series. This paper proposes a concept of boost inverter topology for converting fuel dc supply to a three phase supply. The main advantage of the proposed boost inverter method include ability to deliver the operations of both boosting and inversion of the power in only one stage, compactness, and economical. The output voltage from the fuel cell is a voltage controlled method and output from the battery is a current controlled method. Analysis and Simulation are taken from a $1 \mathrm{~kW}$ prototype.
\end{abstract}

Keywords: Battery Storage System, Boost-Inverter, Fuel Cell, SOFC, Distributed Generator, DC-DC converter

\section{INTRODUCTION}

Distributed generation is referred in general to small generators, starting from a few $\mathrm{kW}$ up to $10 \mathrm{MW}$, whether connected to the utility grid or used as stand-alone at an isolated site. Normally small DGs, in the $5-250 \mathrm{~kW}$ range serve households to large buildings (either in isolated or grid-connected configuration). DG technologies can be categorized to renewable and non-renewable DGs. Renewable energy technologies are in general sustainable (i.e., their energy source will not run out) and cause little or no environmental damage; they include: Solar photovoltaic, Solar thermal, Wind, Geothermal, Tidal, Low-head (small) hydro, Biomass and biogas and Hydrogen fuel cells (hydrogen generated from renewable resources). Nonrenewable energy technologies are referred to those that use some type of fossil fuel such as gasoline, diesel, oil, propane, methane, natural gas, or coal as their energy source.

This paper compared with different types of dc-dc converters and $\mathrm{dc}-\mathrm{ac}$ inverters, including voltage source and current source, e.g., a boost converter followed by a voltage source based inverter, single-stage current source based inverter, and z-source inverter. Specifically, CSI and zsource inverters provide boost and inverter functions in a only one and a wide input voltage range, while limited input voltage lower than the peak grid voltage and insufficient voltage gain are considered. In three-phase boost-inverter topology was proposed including sliding mode control technique and small signal analysis. However, this paper also introduced the boost-inverter topology in the context of a complete three-phase stand-alone energy conversion system based on such topology and sourced by an FC while addressing specific converter and overall control design requirements of the $\mathrm{FC}$ that needs to be supported by a battery based back-up unit3. For instance, the proposed three-phase stand-alone FC power supply can be used as a remote area power supply. Petrol etc.

\section{FUEL CELL}

The first references to hydrogen fuel cells appeared in 1838 . In a letter dated October 1838 but published in the December 1838 edition of The London and Edinburgh 
Philosophical Magazine and Journal of Science, Welsh physicist and barrister William Grove wrote about the development of his first crude fuel cells. He used a combination of sheet iron, copper and porcelain plates, and a solution of sulphate of copper and dilute acid. In a letter to the same publication written in December 1838 but published in June 1839, German physicist Christian discussed the first crude fuel cell that he had invented. His letter discussed current generated from hydrogen and oxygen dissolved in water.

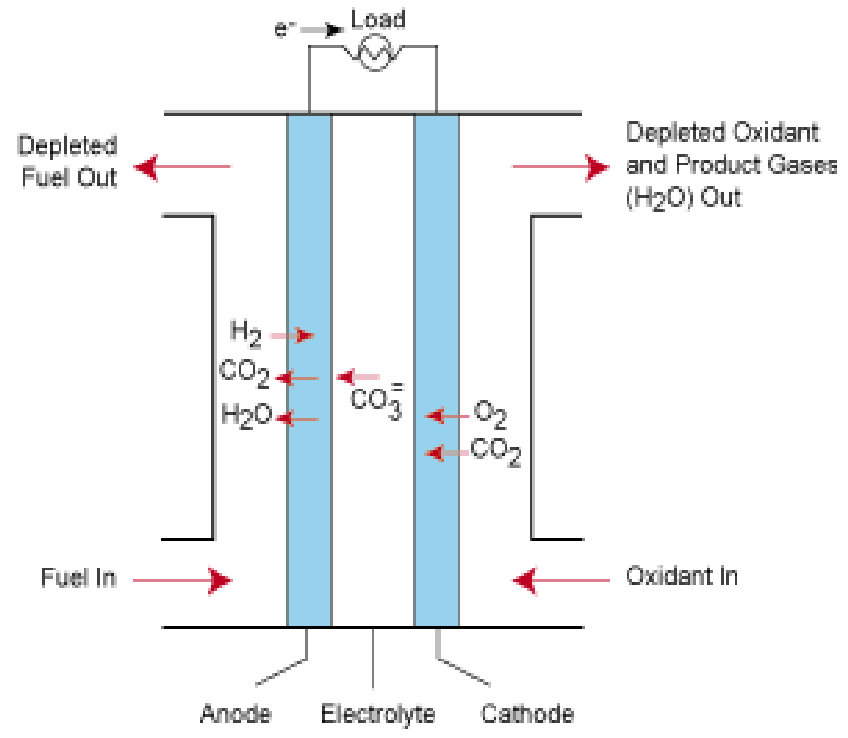

Fig. 1.0 Fuel cell Internal Structure

\section{PROPOSED FC ENERGY SYSTEM}

The main objective of this paper is to propose a 3-phase FC stand-alone power supply having only single energy conversion converter along with a back-up unit is shown in Figure 1.1 The cost of this proposed system is reduced by making the multi stage conversion system with a single stage system, i.e. boost-inverter due to this the switching losses and conduction losses are also reduced.

Generally, the diagram shown in Figure 1.1 shows that boost converter is followed by the Fuel Cell and the back-up energy storage system, these two converters are connected at the same bus and output from the boost inverter is a three phase $\mathrm{AC}$ and it is connected to three phase balanced star connected resistive load4. The Fuel Cell system has operated in current mode controlled bidirectional converter for battery converter to support the Fuel Cell.

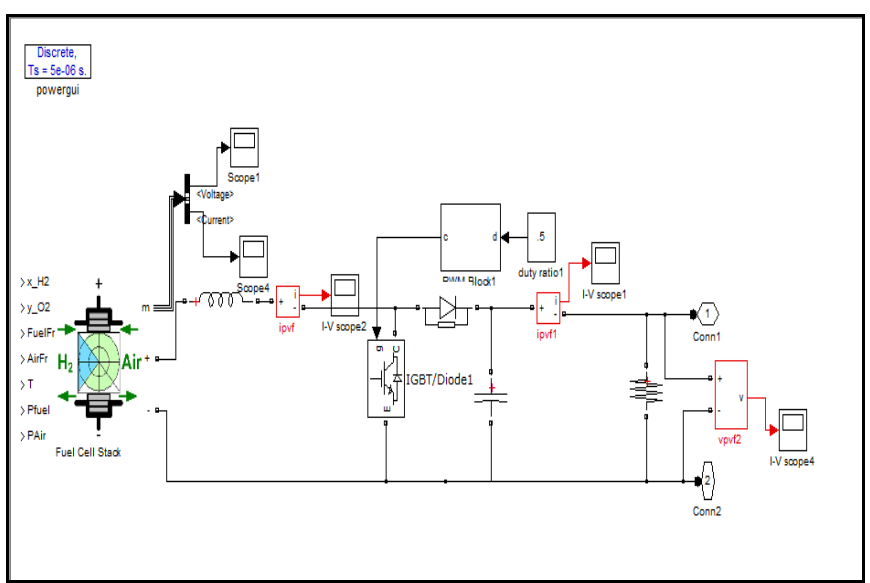

Fig. 1.1 Proposed full cell model.

In this proposed concept the $3-\varnothing$ boost inverter is separated to three individual converters for three phase arms and connected to three individual balanced loads, as shown in Figure 1.2

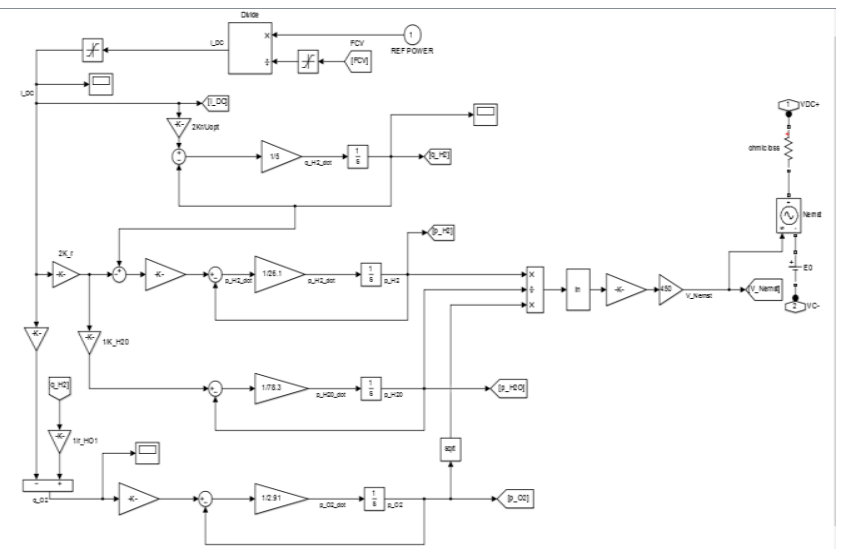

Fig 1.2. Boost inverter model

An Inverter power circuit has to Convert DC to 3 phase AC voltage. Inverter recued two power supply for Inverter power circuit. SMPS power supply input DC requirement. Input power supply for Drive and protection circuit Consisting of 12-0-12 transformer/ used (IN 4007, 1.5A, 240V) diode bridge rectifier. Circuit and 470uf 25v capacitor we required but we have used fixe $12 \mathrm{v}$ dc supply so I have used voltage controller IC LM 78012.In protection circuit also used 12-0- 12 transformer, 1.5 ampere and (IN 4001, 1A, 50V) diode module, 220uf, 16v capacitor used and variable 12volt $\mathrm{dc}$ to convert (voltage controller IC LM7812) fix 12 volt. A power circuit in Inverter I have required 110 volt DC supply for convert three phase AC supply [8], [9]. We have required smps supply for some practical experiment results. A power circuit is 3 phase bridge inverter using IGBTs. LCL filter with load or grid current is 2 Ampere and supply voltage is 440 volt. 


\section{SIMULATION DIAGRAM AND WAVEFORMS}

The modeling of SOFC is carries out based on the assumptions made that the fuel cell temperature is made to be constant; the fuel cell gasses are ideal and the Nernst's equation applicable to the cell. By Nernst's equation output fuel cell dc voltage Vfc across stack of the fuel cell At current I is given by the Simulink Models of Fuel Cell System the fuel system designed in this work for distributed generated grid connected applications consists of the solid oxide fuel cell, CUK converter, three phase inverter and the load. The three phase inverter is selected because most of the loads are three phases in general. The overall Simulink model diagram is shown in figure 2.0 and followed by the model Designs of the individual blocks of SOFC, converters. Now we design and this fuel cell used in our power system modal and find all wave forms in figure in shown in Figure 2.1 and Figure 2.2 is final Our MATLAB Modal results for current and voltage in grid systems.

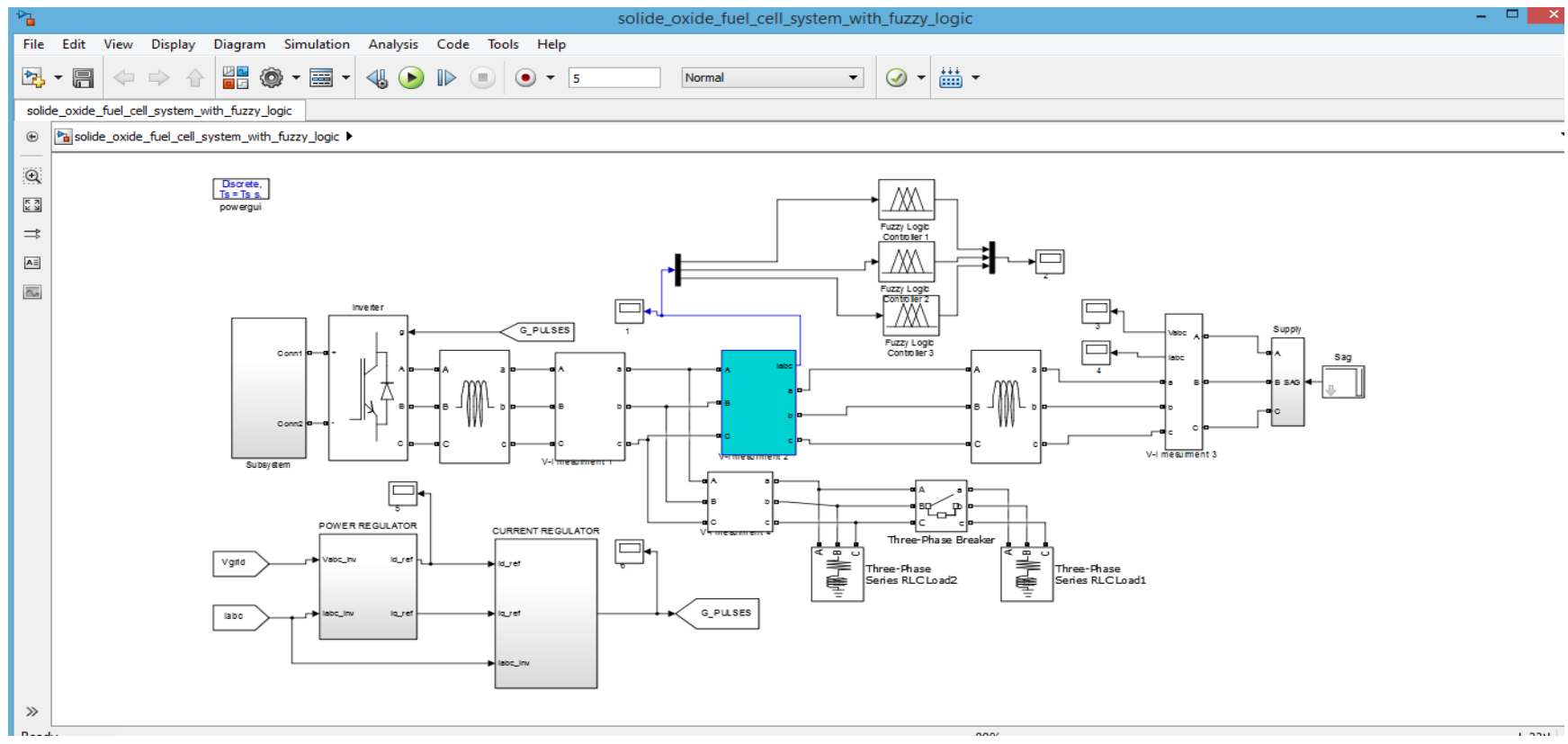

Fig. 2.0 Simulink model

From the above simulation results it can be identified to meet the load changes in the power system can be effectively be controlled by incorporating the FC system as they are fed constant output voltages. The FC output can be controlled by controlling the internal parameters of the fuel cell.

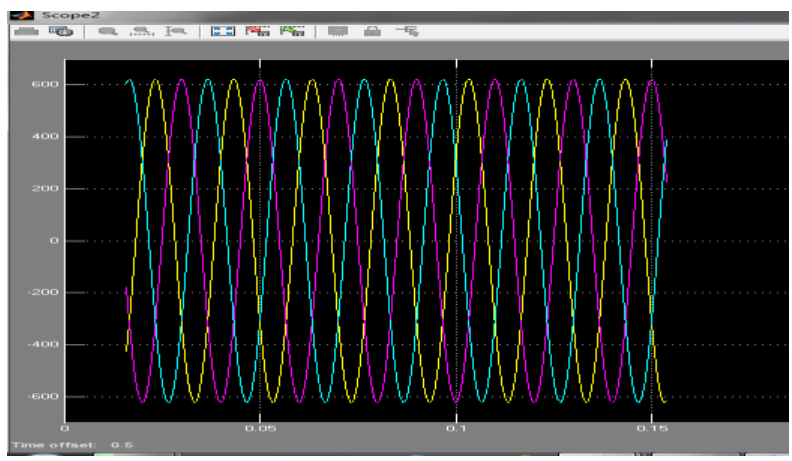

Fig 2.1 Voltage ( $\left.\mathrm{V}_{\mathrm{ABC}}\right)$ Three Phase Waveform.

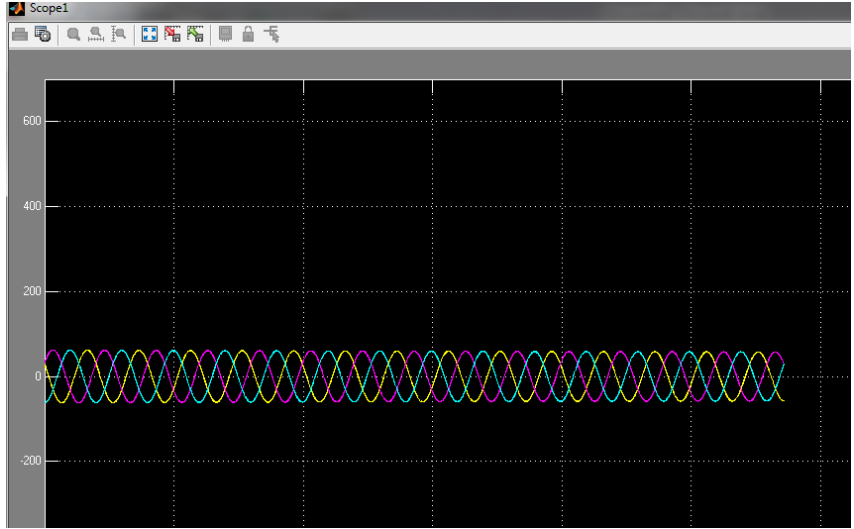

Fig 2.2 Current Waveform

\section{CONCLUSION}

Dynamic modeling of solid-oxide fuel cell with three phase inverter has been performed to analyze its load behavior as distributed generator in a grid connected power system. The response of the system to step changes in load demand are 
presented along with the analysis of the simulated results. It has been observed that the fluctuations in the output voltages in the power system due to load variations are taken care of by the SOFC very closely. An efficient dynamic model of Solid Oxide Fuel Cell has also been developed which can supply active power maintaining inverter voltage as desired. The combined system reduces the cost of power generation as well as the level of pollution reducing the fuel consumption enables comprehensive quantitative and qualitative analysis.

\section{REFERENCES}

[1] Rajendra Aparnathi and Ved vyas Dwivedi, "L-C-L filter base 3Phase Inverter," ebook in Germany lambert publication, 8th Oct2012

[2] Bin Lu, Yaoyu Li, Xin Wu and Zhongzhou Yang, "A Review of Recent Advances in Wind Turbine Condition Monitoring and Fault Diagnosis"

[3] Hector A. Pulgar-Painemal, Peter W. Sauer, "Doubly- Fed Induction Machine in Wind Power Generation"

[4] D.Aouzellag , K.Ghedamsi, E.M.Berkouk" Power Control of a Variable Speed Wind Turbine Driving an DFIG"

[5] Kenneth E. Okedu "Stability Enhancement of DFIGbased Variable Speed Wind Turbine with a Crowbar by FACTS Device as Per Grid Requirement" International Journal Of Renewable Energy Research, Vol.2, No.3, 2012

[6] J. T. Brown "Solid Oxide Fuel Cell Technology, "IEEE Transactions on Energy Conversion, Vol. 3, No. 2, June

[7] Yulei Sun, Sathyendra Ghantasala and Nael H. El-Farra "Networked Control of Distributed Energy Resources: Application to Solid Oxide Fuel Cells" 2009 American Control Conference Hyatt Regency Riverfront, St. Louis, MO, USA, June 10-12, 2009. 